\section{OAK RIDGE NATIONAL. \\ LABORATORY}

\section{MARTIN MARIETTA}

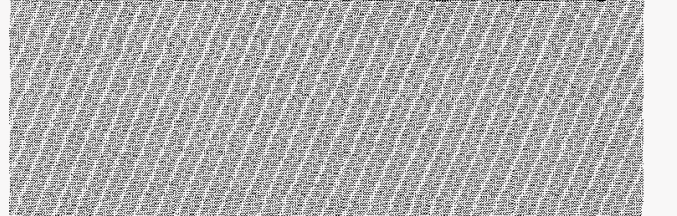

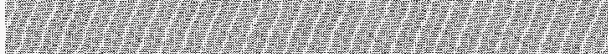

1.

1.t.

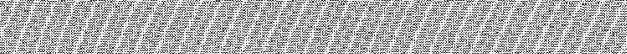

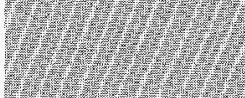

3.t.

\section{3.:}

(1)

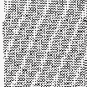

\section{H.t.}

\section{(1)}
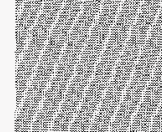

\section{3.t.}

\section{Radiological Verification} Survey Results at the Pompton Plains Railroad Spur, Pequannock, New Jersey (PJ008V)

R. E. Rodriguez

C. A. Johnson

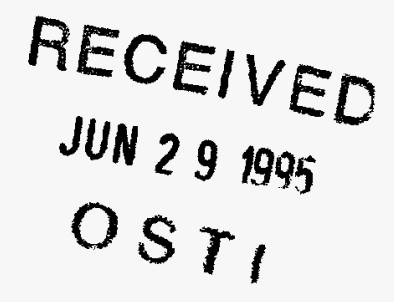


This report has been reproduced directly from the best available copy.

Available to DOE and DOE contractors from the Office of Scientific and Technical Information, P.O. Box 62, Oak Ridge, TN 37831; prices available from (615) 576-8401, FTS 626-8401.

Available to the public from the National Technical Information Service, U.S. Department of Commerce, 5285 Port Royel Rd., Springfield, VA 22161.

This report was prepared as an account of work sponsored by an agency of the United States Government. Neither the United States Government nor any agency thereof, nor any of their employees, makes any warranty, express or implied, or assumes any legal liability or responsibility for the accuracy, completeness, or usefulness of any information, apparatus, product, or process disclosed, or represents that its use would not infringe privately owned rights. Reference herein to any specific commercial product, process, or service by trade name, trademark, manutacturer, or otherwise, does not necessarily constitute or imply its endorsement, recommendation, or favoring by the United States Government or any agency thereol. The views and opinions of authors expressed herein do not necessarily state or reflect those of the United States Government or any agency thereof. 


\section{DISCLAIMER}

Portions of this document may be illegible in electronic image products. Images are produced from the best available original document. 
HEALTH SCIENCES RESEARCH DIVISION

Environmental Restoration and Waste Management Non-Defense Programs

(Activity No. EX 2020010 ; ADS317AEX)

\title{
Radiological Verification Survey Results at the Pompton Plains Railroad Spur, Pequannock, New Jersey (PJ008V)
}

\author{
R. E. Rodriguez and C. A. Johnson
}

Date issued —May 1995

Investigation Team

R. D. Foley - Measurement Applications and Development Manager

R. E. Rodriguez - Survey Team Leader

Survey Team Members

$\begin{array}{ll}\text { R. E. Rodriguez } & \text { D. E. Rice }\end{array}$

V. P. Patania

P. F. Tiner

A. C. Butler*

W. H. Shinpaugh*

*Midwest Technical, Inc.

Work performed by the

Measurement Applications and Development Group

Prepared by the

OAK RIDGE NATIONAL LABORATORY

Oak Ridge, Tennessee 37831-6285

managed by

LOCKHEED MARTIN ENERGY SYSTEMS, INC.

for the

U. S. DEPARTMENT OF ENERGY

under contract DE-AC05-84OR21400 


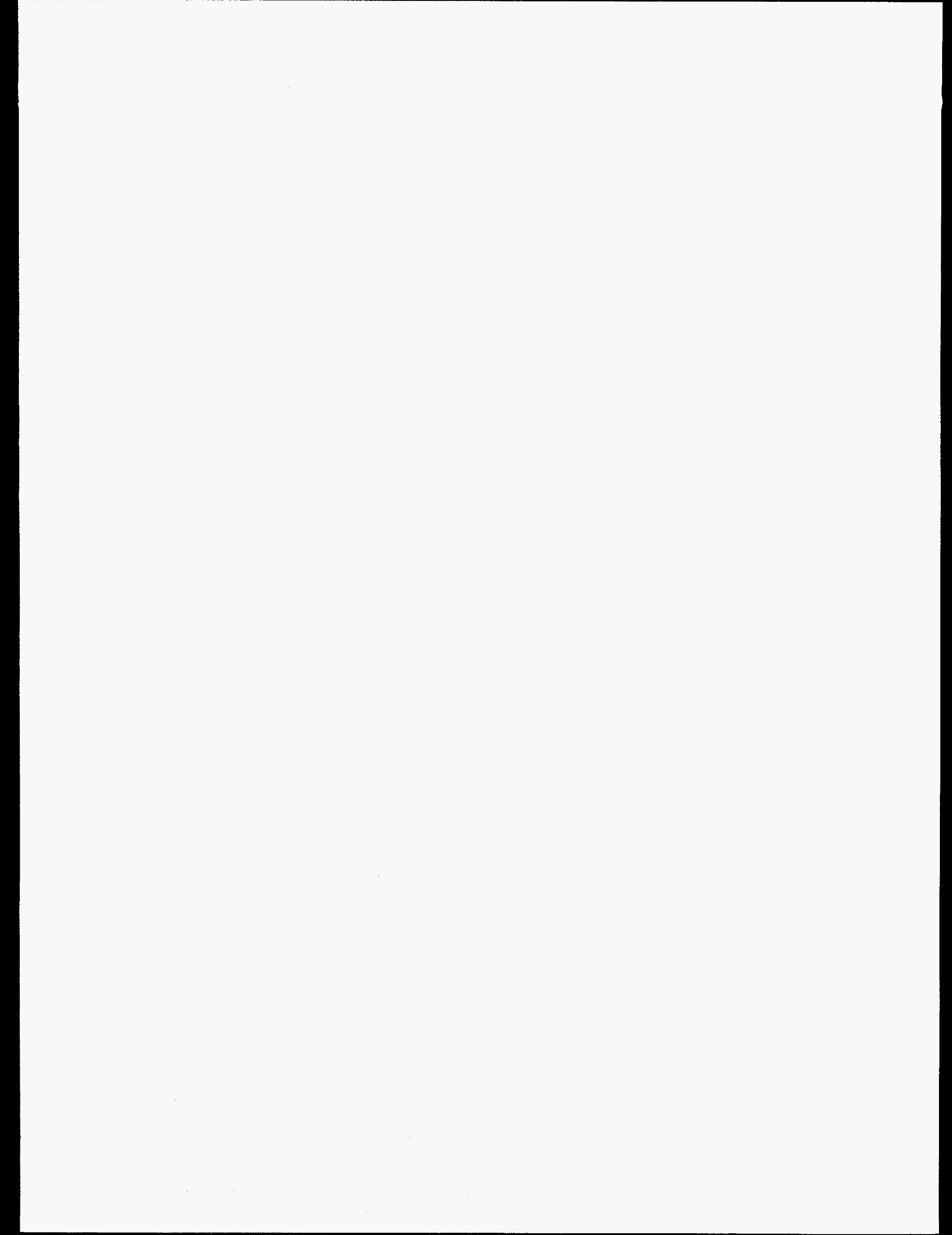




\section{CONTENTS}

LIST OF FIGURES

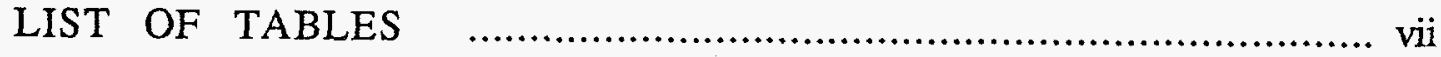

ACKNOWLEDGMENTS .................................................. ix

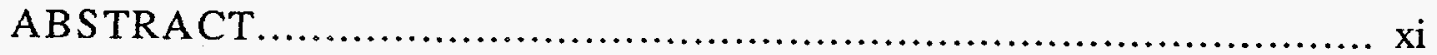

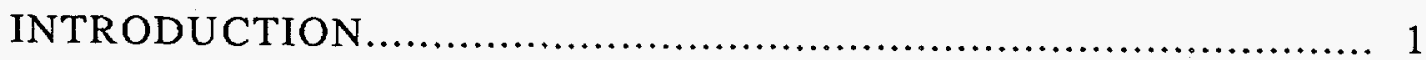

SCOPE OF THE SURVEY .............................................. 2

VERIFICATION SURVEY AND ANALYSIS................................. 2

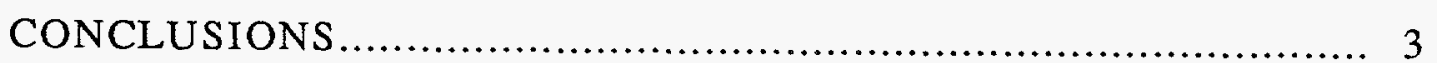

\section{DISCLAIMER}

This report was prepared as an account of work sponsored by an agency of the United States Government. Neither the United States Government nor any agency thereof, nor any of their employees, makes any warranty, express or implied, or assumes any legal liability or responsibility for the accuracy, completeness, or usefulness of any information, apparatus, product, or process disclosed, or represents that its use would not infringe privately owned rights. Reference herein to any specific commercial product, process, or service by trade name, trademark, manufacturer, or otherwise does not necessarily constitute or imply its endorsement, recommendation, or favoring by the United States Government or any agency thereof. The views and opinions of authors expressed herein do not necessarily state or reflect those of the United States Government or any agency thereof. 


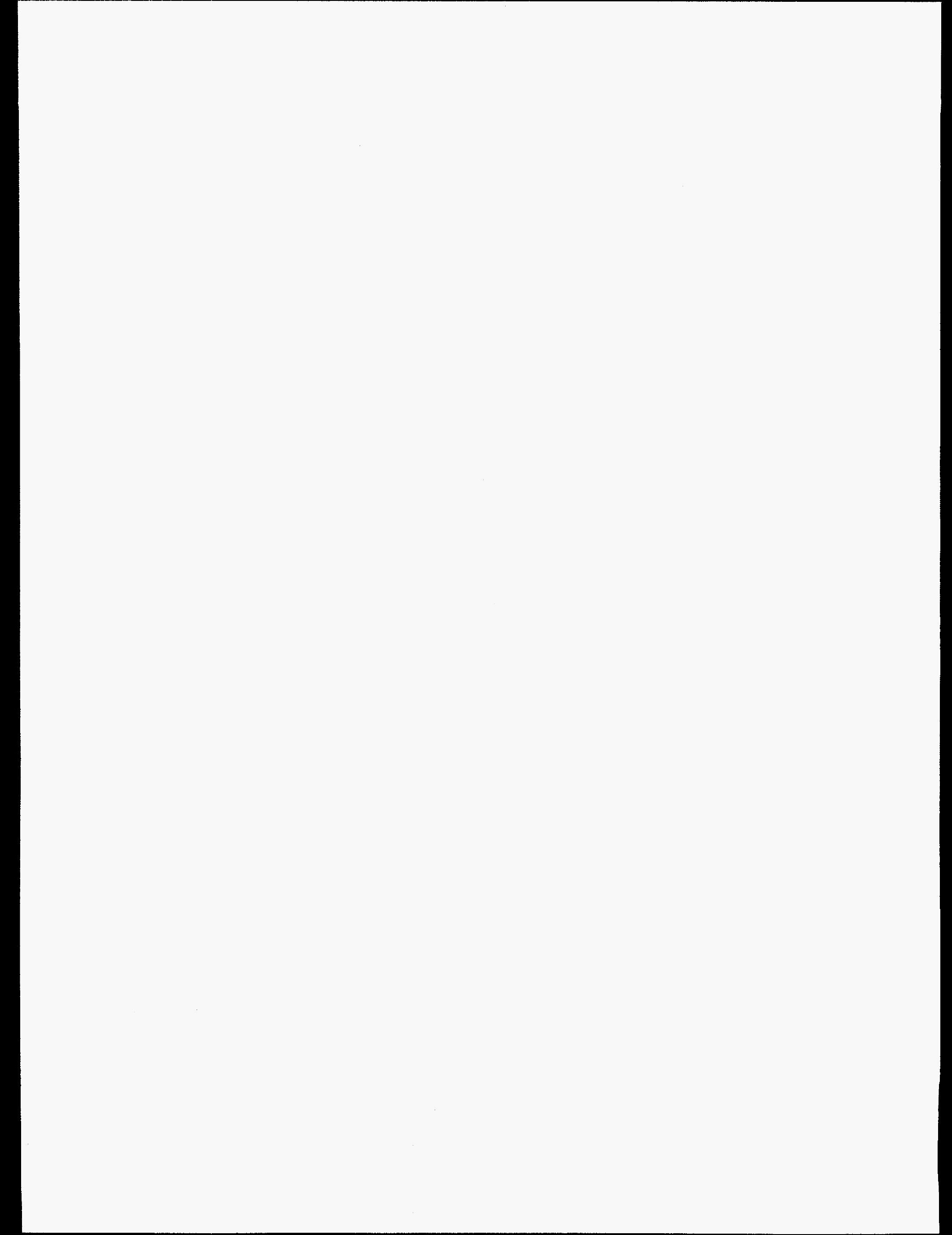




\section{LIST OF FIGURES}

1 Diagram showing general location of the Wayne Interim Storage Site (WISS) relative to the Wayne and Pequannock, New Jersey vicinity properties.

2 Diagram of the property at the Pompton Plains Railroad Spur (PPRS), Pequannock, New Jersey showing soil sampling locations and gamma measurements at one meter. 


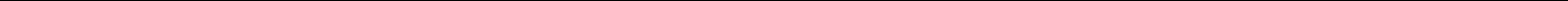


LIST OF TABLES

1 Concentrations of radionuclide in soil at the Pompton Plains railroad spur (PPRS), Pequannock, New Jersey (PJ008V)..........................

6

vii 


\section{ACKNOWLEDGMENTS}

Research for this project was sponsored by the Office of Environmental Restoration, U. S. Department of Energy, under contract DE-AC05-84OR21400 with Lockheed Martin Energy Systems, Inc. The authors wish to acknowledge the contributions of V. P. Patania, D. A. Roberts, D. A. Rose, and J. M. Lovegrove of the Measurement Applications and Development Group for participation in the sample preparation and analyses, editing, graphics, and reporting of data for this survey. The surveying assistance of the staff on the survey team is also gratefully acknowledged. 


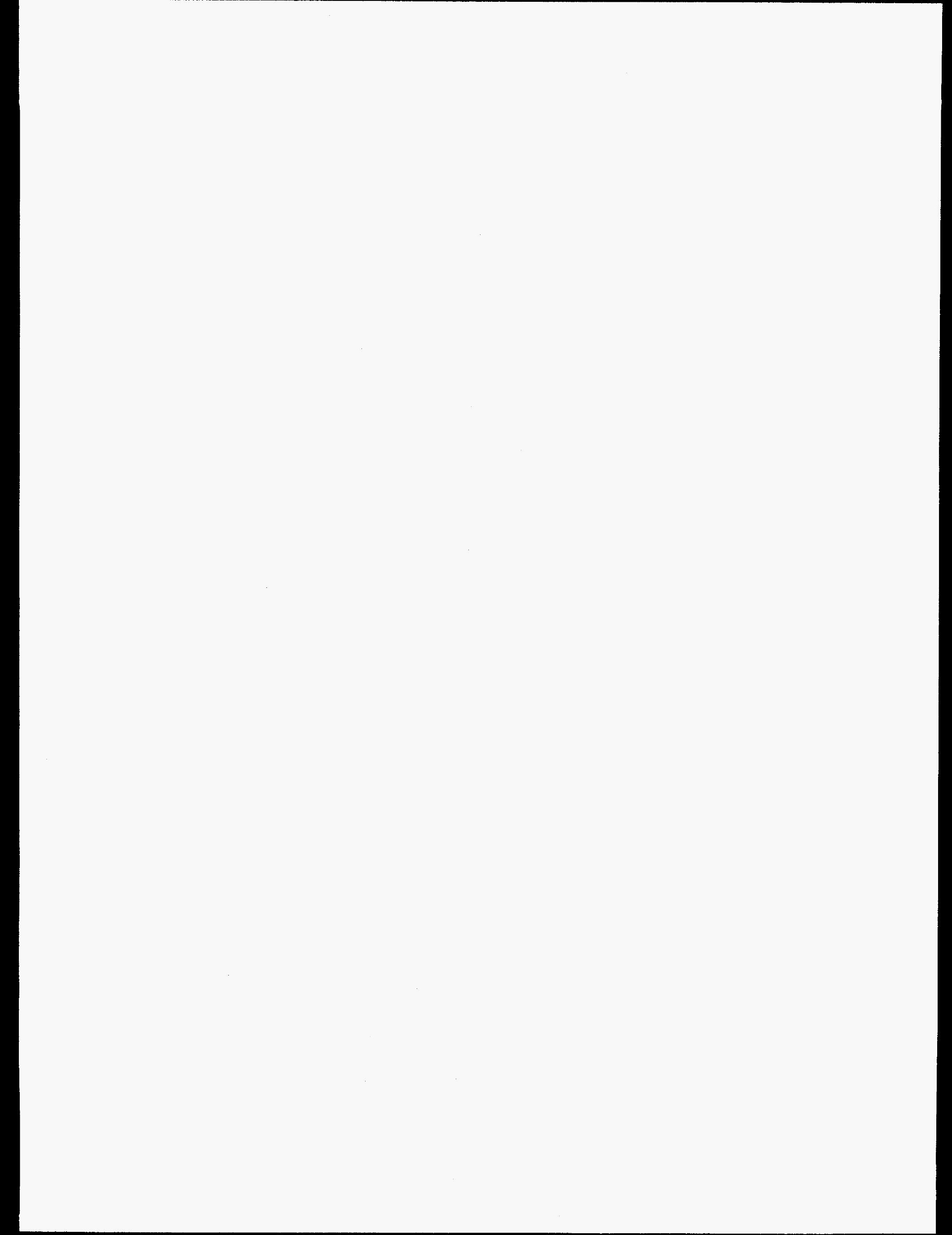




\begin{abstract}
The U. S. Department of Energy (DOE) conducted remedial action during 1993 at the Pompton Plains railroad spur and eight vicinity properties in the Wayne and Pequannock Townships in New Jersey as part of the Formerly Utilized Sites Remedial Action Program (FUSRAP). These properties are in the vicinity of the DOE-owned Wayne Interim Storage Site (WISS), formerly the W. R. Grace facility. The property at the Pompton Plains Railroad Spur, Pequannock, New Jersey is one of these vicinity properties.

At the request of DOE, a team from Oak Ridge National Laboratory conducted an independent radiological verification survey at this property. The purpose of the survey, conducted between September and December 1993, was to confirm the success of the remedial actions performed to remove any radioactive materials in excess of the identified guidelines. The verification survey included surface gamma scans and gamma readings at 1 meter, beta-gamma scans, and the collection of soil and debris samples for radionuclide analysis.
\end{abstract}

Results of the survey demonstrated that all radiological measurements on the property at the Pompton Plains railroad spur were within applicable DOE guidelines. Based on the results of the remedial action data and confirmed by the verification survey data, the portions of the site that had been remediated during this action successfully meet the DOE remedial action objectives. 


\section{Radiological Verification Survey Results at the Pompton Plains Railroad Spur (PPRS), Pequannock, New Jersey (PJ008V)*}

\section{INTRODUCTION}

As part of the Formerly Utilized Sites Remedial Action Program (FUSRAP), the Department of Energy (DOE) conducted a remedial action project in 1993 at several residential vicinity properties in the Townships of Pequannock and Wayne, New Jersey, and at the Pompton Plains railroad spur (PPRS) in Pequannock, New Jersey. Figure 1 shows the general location of these vicinity properties.

From September to December 1993, a team from the Measurements Application and Development Group, Oak Ridge National Laboratory (ORNL), conducted radiological verification surveys of these properties in the Wayne and Pequannock, New Jersey areas. The PPRS in Pequannock was one of the properties that had previously been surveyed and designated for remedial action. After completion of the remediation, the team from ORNL conducted a radiological verification survey of this property at the request of $\mathrm{DOE}$. The verification survey consisted primarily of a complete gamma scan of the area and the collection of soil samples for radionuclide analysis.

This report describes the radiological verification survey of the now-abandoned Pompton Plains railroad spur, Pequannock, New Jersey conducted by ORNL at the request of the Department of Energy's Office of Environmental Restoration.

The PPRS is an old railroad spur located at the east end of Peck Ave. in Pequannock Township, owned by the New York, Susquehanna, and Western Railroad. The PPRS is a flat, open area approximately 1 mile west of the former processing plant (the now DOE-owned Wayne Site). The plant received and processed monazite sand containing high concentrations of ${ }^{232} \mathrm{Th}$. The spur was used to transfer the raw source material from rail cars to trucks for delivery to the processing plant on Black Oak Ridge Road. The portion of the property where Peck Ave. abuts the railroad spur (see Fig. 2) became radioactively contaminated by spills of unprocessed monazite sands that occurred during transfer of the material from rail cars to trucks.

A walkover survey of the property (a technician walks slowly over the property swinging a detection probe at $\sim 1-2$ inches from the ground surface) was conducted in October, November, and December 1993 by ORNL's Measurement Applications and Development Group. The purpose of the survey, which included the remediated area and adjacent tracks, was to determine whether any radiological residues above guidelines remained on the property.

A field survey drawing showing 10-m grids and indicating soil sampling locations and gamma radiation measurements is included in this report as Fig. 2.

* The survey was performed by members of the Measurement Applications and Development Group of the Health Sciences Research Division at Oak Ridge National Laboratory under DOE contract DE-AC05-84OR21400. 


\section{SCOPE OF THE SURVEY}

A comprehensive description of the survey methods and instrumentation used in this survey is given in Procedures Manual for the ORNL Radiological Survey Activities (RASA) Program, ORNL/TM-8600 (April 1987), and Measurement Applications and Development Group Guidelines, ORNL-6782 (January 1995).

The radiological survey of this property included: (1) a surface gamma scan of the remediated area of the spur, with supplementary beta-gamma scans of the tracks, and (2) the collection of surface and subsurface soil samples for analysis.

Gamma radiation levels were determined using a portable sodium iodide ( $\mathrm{NaI})$ gamma scintillation detector connected to a Victoreen ratemeter. Measurements were recorded and converted to $\mu \mathrm{R} / \mathrm{h}$. Because $\mathrm{NaI}$ gamma scintillators are energy dependent, measurements of gamma radiation levels in counts per minute (CPM) are normalized to pressurized ionization chamber (PIC) measurements to estimate gamma exposure rates in $\mu \mathrm{R} / \mathrm{h}$. Beta-gamma measurements were taken with a Geiger-Mueller (GM) pancake to help detect surface contamination.

Surface $(0-15 \mathrm{~cm}$, or 0 to 6 in) and subsurface $(15-45 \mathrm{~cm}$, or 6 to 18 in) soil samples were collected randomly over the property. Confirmatory samples were taken from the remediated area where slightly elevated gamma or beta-gamma levels had been identified. These are referred to as biased samples and are labeled as B1 - B15. Systematic samples (S1-S8) were taken at locations irrespective of gamma exposure rates. Locations of the samples are shown in Fig. 2, and results of the analysis are shown in Table 1.

Direct measurement results presented in this report are gross readings; background radiation levels have not been subtracted. Similarly, background radiation levels have not been subtracted from radionuclide concentrations measured in environmental samples.

\section{VERIFICATION SURVEY AND ANALYSIS}

Gamma measurements at one meter from the surface ranged from 8 to $13 \mu \mathrm{R} / \mathrm{h}$ as shown in Fig. 2. Surface gamma measurements generally ranged from 10 to $33 \mu \mathrm{R} / \mathrm{h}$ on contact with the surface soil in the remediated area.

Surface and subsurface soil samples were collected from the remediated area. During beta and gamma scans, several small areas of surface contamination were detected on top of the railroad ties. Some samples were scraped from between and on top of the railroad ties where contaminated soil had inadvertently been deposited during the remediation process (samples B3, B5, B6, B7, B8 and B9). Because these areas on the tracks were subsequently remediated and re-scanned for beta and gamma radiation to ensure the removal of all contamination, these samples do not appear in Table 1 . All samples were analyzed for radium $\left({ }^{226} \mathrm{Ra}\right)$, thorium $\left({ }^{232} \mathrm{Th}\right)$, and uranium $\left({ }^{238} \mathrm{U}\right)$. 
Results of the soil analyses are in picocuries per gram $(\mathrm{pCi} / \mathrm{g})$ and are shown in Table 1. Radionuclide concentrations of ${ }^{226} \mathrm{Ra}$ and ${ }^{232} \mathrm{Th}$ in systematic soil samples ranged from 0.58 to $0.97 \mathrm{pCi} / \mathrm{g}$ and from 0.92 to $3.0 \mathrm{pCi} / \mathrm{g}$, respectively. Concentrations of $226 \mathrm{Ra}$ and $232 \mathrm{Th}$ in biased samples ranged from 0.6 to 2.1 and 1.4 to $11 \mathrm{pCi} / \mathrm{g}$, respectively. The maximum concentration of $11 \mathrm{pCi} / \mathrm{g} 232 \mathrm{Th}$ was found in sample $\mathrm{B} 11$. Although samples B11, B12, B14, and B15 were slightly above guidelines (Table 1), all the areas of elevated gamma radiation in which the samples were taken were no more than $1 \mathrm{~m}^{2}$ in size. Thus, all these values are well below the DOE guideline for these radionuclides in soil which is 5 and $15 \mathrm{pCi} / \mathrm{g}$ above background when averaged over 100 $\mathrm{m}^{2}$ for surface and subsurface soil, respectively. ${ }^{*}$

Concentrations of $238 \mathrm{U}$ in soil ranged from 0.64 to $1.3 \mathrm{pCi} / \mathrm{g}$ in the systematic samples, and from 0.71 to $4.5 \mathrm{pCi} / \mathrm{g}$ in biased samples. These values are well below the site specific guidelines for uranium in soil. ${ }^{* *}$

\section{CONCLUSIONS}

Generally, gamma measurements on the property at the Pompton Plains railroad spur in Pequannock, New Jersey were comparable to the average values for the area. Although slightly elevated gamma measurements were detected on surface contact with the remediated area and railroad tracks, they were within the range of background levels.

The previously remediated area was thoroughly investigated for radionuclide residues. The results of soil radionuclide analysis for ${ }^{238} \mathrm{U},{ }^{226} \mathrm{Ra}$, and ${ }^{232} \mathrm{Th}$ indicate that all soil concentration measurements are within the limits prescribed by DOE radiological guidelines.

Based on the results of the remedial action data and confirmed by the verification survey data, all radiological measurements fall below the limits prescribed by DOE radiological guidelines established for this site. It is concluded that the portions of the site which had been remediated during this action successfully meet the DOE remedial action objectives.

\footnotetext{
${ }^{*}$ For residential properties in this area, the guideline for ${ }^{232} \mathrm{Th}$ is $5 \mathrm{pCi} / \mathrm{g}$ for both surface and subsurface soil.

${ }^{* *}$ DOE guidelines for uranium are derived on a site-specific basis. Guidelines of $100 \mathrm{pCi} / \mathrm{g}$ have been applied to this FUSRAP site. Source: J. W. Wagoner II, Director, Division of Off-Site Programs, Office of Environmental Restoration, U. S. Department of Energy, personal communication to L. K. Price, Director, Former Sites Restoration Division, Oak Ridge Field Office, U. S. DOE, April 25, 1995.
} 


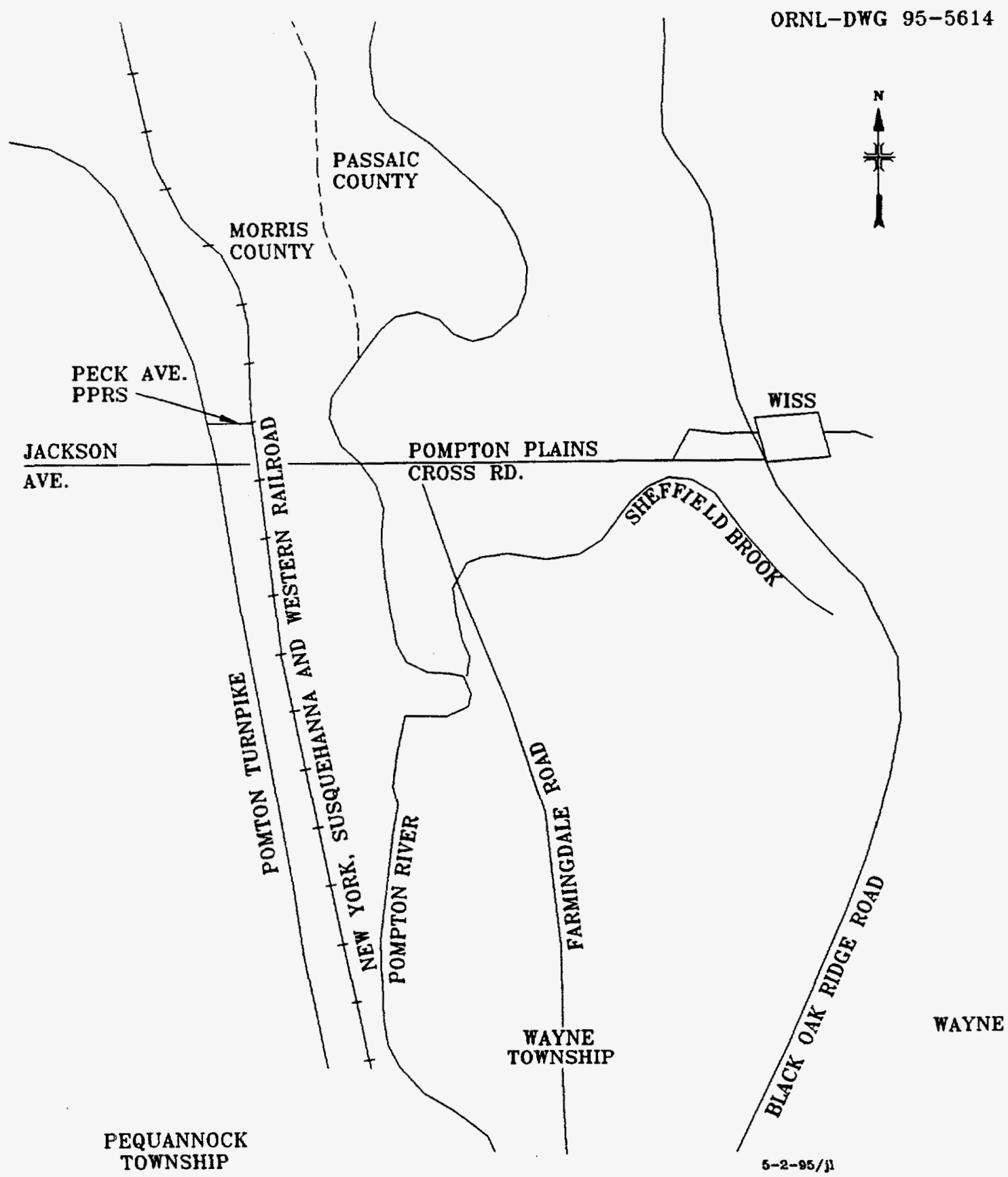

Fig. 1. Diagram showing general location of the Wayne Interim Storage Site (WISS) relative to the Wayne and Pequannock, New Jersey vicinity properties. 


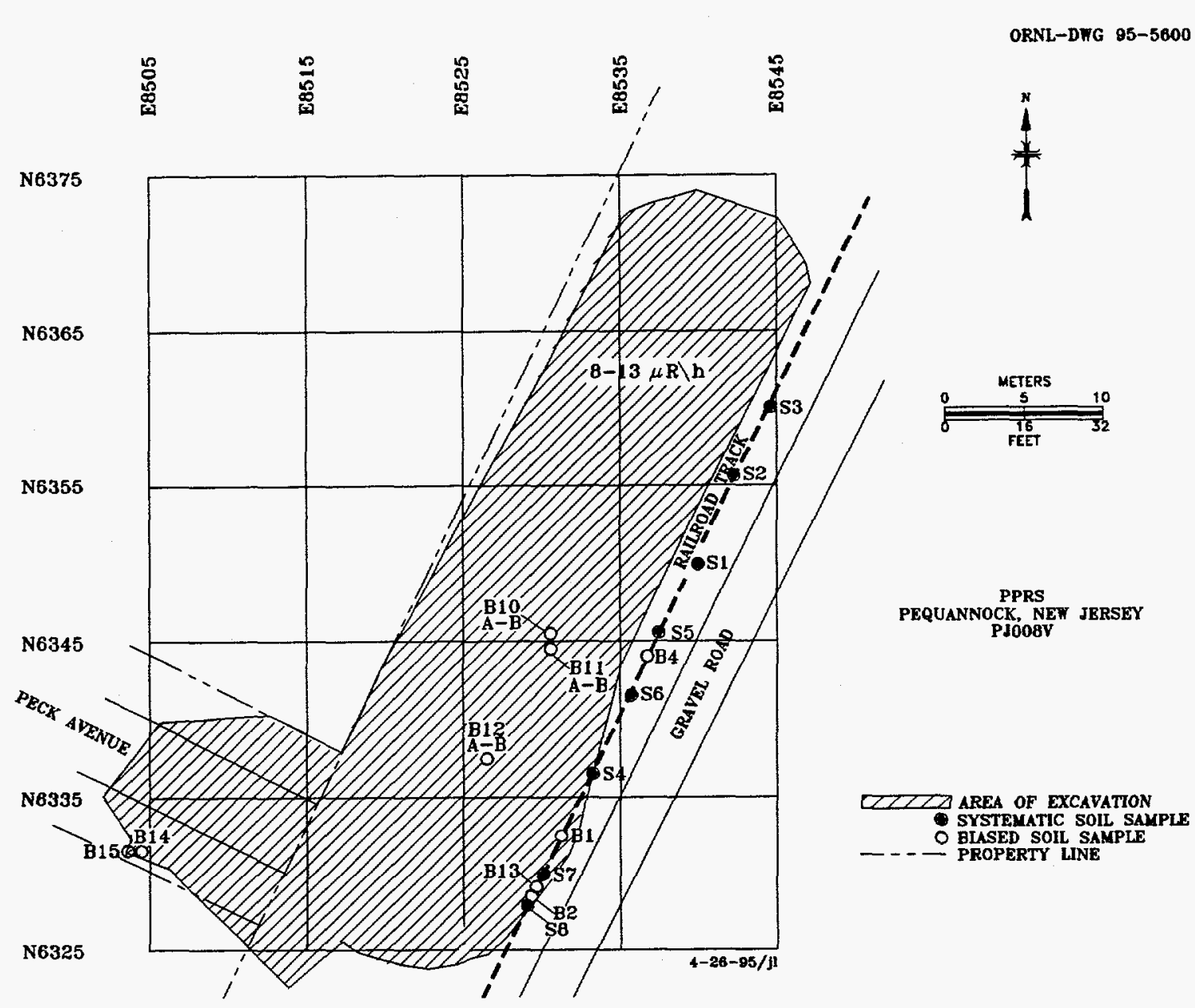

Fig. 2. Diagram of the property at the Pompton Plains railroad spur (PPRS), Pequannock, New Jersey showing soil sampling locations and gamma measurements at one meter. 
Table 1. Concentrations of radionuclides in soil at the Pompton Plains railroad spur (PPRS), Pequannock, New Jersey (PJ008V)

Sample
numbera $\quad \begin{gathered}\text { Grid } \\ \text { location }\end{gathered} \quad \begin{gathered}\text { Depth } \\ (\mathrm{cm})\end{gathered}$

Radionuclide concentration $(\mathrm{pCi} / \mathrm{g}) b$

$$
226 \mathrm{Ra}
$$

$232 \mathrm{Th}$

$238 \mathrm{U}$

Systematic soil samplesc

$\begin{array}{llllll}\text { S1 } & 6350 \mathrm{~N}, 8540 \mathrm{E} & 0-15 & 0.85 \pm 0.1 & 0.95 \pm 0.1 & 1.1 \pm 0.4 \\ \text { S2 } & 6355 \mathrm{~N}, 8543 \mathrm{E} & 0-15 & 0.68 \pm 0.1 & 0.92 \pm 0.2 & 1.1 \pm 0.42 \\ \text { S3 } & 6360 \mathrm{~N}, 8545 \mathrm{E} & 0-15 & 0.58 \pm 0.1 & 1.00 \pm 0.1 & 0.89 \pm 0.4 \\ \text { S4 } & 6337 \mathrm{~N}, 8533 \mathrm{E} & 0-15 & 0.90 \pm 0.1 & 1.2 \pm 0.2 & 0.85 \pm 0.5 \\ \text { S5 } & 6346 \mathrm{~N}, 8538 \mathrm{E} & 0-15 & 0.97 \pm 0.1 & 3.0 \pm 0.5 & 1.3 \pm 0.4 \\ \text { S6 } & 6342 \mathrm{~N}, 8536 \mathrm{E} & 0-15 & 0.84 \pm 0.1 & 2.0 \pm 0.3 & 1.1 \pm 0.5 \\ \text { S7 } & 6330 \mathrm{~N}, 8530 \mathrm{E} & 0-15 & 0.63 \pm 0.1 & 1.0 \pm 0.2 & 0.82 \pm 0.4 \\ \text { S8 } & 6328 \mathrm{~N}, 8528 \mathrm{E} & 0-15 & 0.62 \pm 0.1 & 1.6 \pm 0.2 & 0.64 \pm 0.5\end{array}$

\section{Biased samplesd,e}

$\begin{array}{lcccll}\text { B1 } & 6333 N, 8531 \mathrm{E} & 0-15 & 0.85 \pm 0.1 & 2.6 \pm 0.2 & 1.1 \pm 0.5 \\ \text { B2 } & 6328 \mathrm{~N}, 8528 \mathrm{E} & 0-15 & 0.69 \pm 0.1 & 2.03 \pm 0.2 & 1.2 \pm 0.4 \\ \text { B4 } & 6344 \mathrm{~N}, 8536 \mathrm{E} & 0-15 & 1.08 \pm 0.1 & 4.04 \pm 0.3 & 1.1 \pm 0.4 \\ & & & & & \\ \text { B10A } & 6346 \mathrm{~N}, 8531 \mathrm{E} & 0-15 & 1.0 \pm 0.1 & 4.07 \pm 0.3 & 0.71 \pm 0.5 \\ \text { B10B } & & 15-30 & 0.88 \pm 0.1 & 2.7 \pm 0.2 & 0.86 \pm 0.4 \\ & & & & & \\ \text { B11A } & 6346 \mathrm{~N}, 8531 \mathrm{E} & 0-15 & 2.1 \pm 0.1 & 11 \pm 0.3 & <1.3 \\ \text { B11B } & & 15-30 & 0.60 \pm 0.1 & 1.4 \pm 0.2 & 0.76 \pm 0.3\end{array}$


Table 1 (continued)

\begin{tabular}{|c|c|c|c|c|c|}
\hline \multirow{2}{*}{$\begin{array}{l}\text { Sample } \\
\text { numbera }\end{array}$} & \multirow{2}{*}{$\begin{array}{c}\text { Grid } \\
\text { location }\end{array}$} & \multirow{2}{*}{$\begin{array}{l}\text { Depth } \\
(\mathrm{cm})\end{array}$} & \multicolumn{3}{|c|}{ Radionuclide concentration $(\mathrm{pCi} / \mathrm{g}) b$} \\
\hline & & & $226 \mathrm{Ra}$ & $232 \mathrm{Th}$ & $238 \mathrm{U}$ \\
\hline $\mathrm{B} 12 \mathrm{~A}$ & $6338 \mathrm{~N}, 8527 \mathrm{E}$ & E $\quad 0-15$ & $1.7 \pm 0.2$ & $8.5 \pm 0.4$ & $4.5 \pm 2.0$ \\
\hline $\mathrm{B} 12 \mathrm{~B}$ & & $15-30$ & $0.97 \pm 0.1$ & $4.4 \pm 1.0$ & $1.3 \pm 0.3$ \\
\hline B13 & $6329 \mathrm{~N}, 8529 \mathrm{E}$ & E $0-15$ & $1.01 \pm 0.1$ & $3.9 \pm 0.2$ & $0.84 \pm 0.5$ \\
\hline B 14 & $6332 \mathrm{~N}, 8504 \mathrm{E}$ & E $0-15$ & $1.4 \pm 0.5$ & $7.2 \pm 0.3$ & $2 \pm 1.0$ \\
\hline B15 & $6332 \mathrm{~N}, 8503 \mathrm{E}$ & E $0-5$ & $1.6 \pm 0.1$ & $10 \pm 1.0$ & $1.1 \pm 0.5$ \\
\hline
\end{tabular}

aLocations of soil samples are shown on Fig. 2.

bIndicated counting error is at the $95 \%$ confidence level $( \pm 2 \sigma)$.

cSystematic samples are taken at locations irrespective of gamma exposure rates.

$d$ Biased samples are taken from areas with elevated gamma exposure rates.

eSamples B3, B5, B6, B7, B8 and B9 are not included in the table (see text). 

ORNL/RASA-95/10

\section{INTERNAL DISTRIBUTION}

\author{
1. B. A. Berven \\ 2. K. J. Brown \\ 3. R. F. Carrier \\ 4. R. D. Foley \\ 5-7. C. A. Johnson \\ 8. M. E. Murray \\ 9. P. T. Owen \\ 10-12. R. E. Rodriguez
}

\author{
13. R. E. Swaja \\ 14. M. S. Uziel \\ 15. J. K. Williams \\ 16. Central Research Library \\ 17-18. Laboratory Records \\ 19. Laboratory Records-RC \\ 20. ORNL Patent Section \\ 21. ORNL Technical Library, $Y-12$ \\ 22-27. MAD Records Center
}

\section{EXTERNAL DISTRIBUTION}

28. W. L. Beck, Oak Ridge Associated Universities, E/SH Division, Environmental Survey and Site Assessment Program, P.O. Box 117, Oak Ridge, TN 37831-0117

29. Jack Russell, Booz-Allen \& Hamilton, Inc., Trevion I Bldg., Suite 210, 12850 Middlebrook Rd., Bethesda, MD 20814

30. James J. Fiore, Director, Office of Eastern Area Programs, Office of Environmental Restoration, EM-24, U.S. Department of Energy, 19901 Germantown Rd., Germantown, MD 20874-1290

31-33. R. R. Harbert, Bechtel Nationa1, Inc., FUSRAP Department, Oak Ridge Corporate Center, 151 Lafayette Drive, P.O. Box 350, Oak Ridge, TN 37831-0350

34-36. J. King, Science Applications International Corporation, P.O. Box 2501, 301 Laboratory Road, Oak Ridge, TN 37831

37. L. K. Price, Director, Former Sites Restoration Division, Oak Ridge Field Office, U.S. Department of Energy, P.O. Box 2001, Oak Ridge, TN 37831-8723

38. James W. Wagoner II, Director, Division of Off-Site Programs, Office of Eastern Area Programs, Office of Environmental Restoration, EM-421, U.S. Department of Energy, 19901 Germantown Rd., Germantown, MD 20874-1290

39-43. W. Alexander Williams, Designation and Certification Manager, Division of OffSite Programs, Office of Eastern Area Programs, Office of Environmental Restoration, EM-421, U.S. Department of Energy, 19901 Germantown Rd., Germantown, MD 20874-1290

44-45. Office of Scientific and Technical Information, U.S. Department of Energy, P.O. Box 62, Oak Ridge, TN 37831

46. Office of Assistant Manager, Energy Research and Development, U.S. Department of Energy, DOE Field Office, P.O.Box 2008, Oak Ridge, TN 37831-6269 